\title{
Interactive comment on "Identification and Source Attribution of Organic Compounds in Ultrafine Particles near Frankfurt International Airport" by Florian Ungeheuer et al.
}

Florian Ungeheuer et al.

vogel@iau.uni-frankfurt.de

Received and published: 18 January 2021

The comment was uploaded in the form of a supplement:

https://acp.copernicus.org/preprints/acp-2020-1091/acp-2020-1091-AC2-

supplement.pdf

Interactive comment on Atmos. Chem. Phys. Discuss., https://doi.org/10.5194/acp-2020-1091, 2020. 